\title{
A Concise Stereoselective Synthesis of the A-Ring Fragment of the Gambieric Acids
}

\author{
J. Stephen Clark,* Thomas C. Fessard and Claire Wilson \\ School of Chemistry, University of Nottingham, University Park, Nottingham, NG7 2RD, UK
}

\section{Supporting Information}

\section{General Information}

Melting points were determined using either Büchi 510 or Reichert hot-stage melting point apparatus. IR spectra were recorded as liquid films or as solutions using a Perkin-Elmer 1600 series FTIR spectrometer. ${ }^{1} \mathrm{H}$ and ${ }^{13} \mathrm{C}$ NMR spectra were recorded using a Bruker AV400 or DRX500 FT spectrometer. ${ }^{1} \mathrm{H}$ NMR data is expressed as chemical shift in ppm from an internal standard of tetramethylsilane followed by multiplicity (s, singlet; d, doublet; $\mathrm{t}$, triplet; q, quartet; m, multiplet), coupling constant(s) J (Hz), and number of protons. ${ }^{13} \mathrm{C}$ NMR chemical shifts are expressed in parts per million downfield of tetramethylsilane. High resolution mass spectra (HRMS) were obtained using an AEI MS902 or VG Micromass 70E mass spectrometer, using electron impact (EI), chemical ionisation (CI) or fast-atom bombardment (FAB). Microanalysis was performed by the microanalysis section of the School of Chemistry, University of Nottingham.

\section{Ketone 6a}

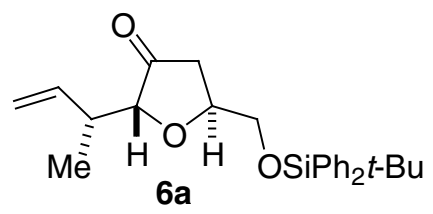

A solution of diazo ketone $\mathbf{5 a}(171 \mathrm{mg}, 0.392 \mathrm{mmol})$ in THF $(10 \mathrm{~mL})$ was slowly added to a solution of $\mathrm{Cu}(\mathrm{acac})_{2}(9.8 \mathrm{mg}, 10 \mathrm{~mol} \%)$ in THF $(10 \mathrm{~mL})$ at reflux. The solution was stirred at reflux for $30 \mathrm{~min}$ and cooled to room temperature. The solvent was removed in vacuo and the residue was purified by flash column chromatography on silica gel (hexane-diethyl ether, 10:1) to afford the ketone $6 \mathbf{a}$ (120 mg, 75\%) as a white solid that was recrystallized from hexane: m.p. 58-59 ${ }^{\circ} \mathrm{C}$; IR $\left(\mathrm{CHCl}_{3}\right) 2932,2859,1753,1112$ $\mathrm{cm}^{-1} ;{ }^{1} \mathrm{H}$ NMR $\left(400 \mathrm{MHz}, \mathrm{CDCl}_{3}\right) \delta$ 7.69-7.63 (m, 4H), 7.47-7.37 (m, 6H), 5.78 (ddd, J = 17.1, 10.5, 8.1 $\mathrm{Hz}, 1 \mathrm{H}), 5.10-5.03(\mathrm{~m}, 2 \mathrm{H}), 4.49-4.43(\mathrm{~m}, 1 \mathrm{H}), 4.06(\mathrm{~d}, \mathrm{~J}=3.7 \mathrm{~Hz}, 1 \mathrm{H}), 3.94(\mathrm{dd}, \mathrm{J}=11.0,3.2 \mathrm{~Hz}, 1 \mathrm{H})$, $3.64(\mathrm{dd}, \mathrm{J}=11.0,2.8 \mathrm{~Hz}, 1 \mathrm{H}), 2.63-2.54(\mathrm{~m}, 1 \mathrm{H}), 2.53-2.49(\mathrm{~m}, 2 \mathrm{H}), 1.18(\mathrm{~d}, \mathrm{~J}=7.0 \mathrm{~Hz}, 3 \mathrm{H}), 1.03(\mathrm{~s}$, 9H); ${ }^{13} \mathrm{C}$ NMR $\left(100 \mathrm{MHz}, \mathrm{CDCl}_{3}\right) \delta 215.5,138.4,135.6,133.0,129.9,127.8,116.3,84.1,75.9,67.5$, 
40.9, 39.1, 26.8, 19.2, 16.8; LRMS (CI, $\left.\mathrm{CH}_{4}\right)$ m/z 409 (M+1, 24), 331 (39), 323 (67), 221 (73), 125

(100); HRMS (CI, $\left.\mathrm{CH}_{4}\right)$ for $\mathrm{C}_{25} \mathrm{H}_{33} \mathrm{SiO}_{3}\left[(\mathrm{M}+\mathrm{H})^{+}\right]$calcd 409.2198, found 409.2199.

\section{Ketone $6 b$}

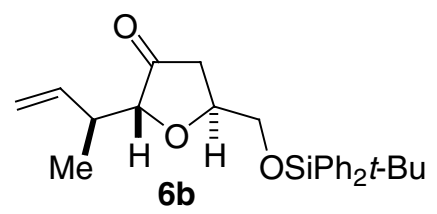

A solution of diazo ketone $\mathbf{5 b}(607 \mathrm{mg}, 1.71 \mathrm{mmol})$ in THF $(10 \mathrm{~mL})$ was slowly added to a refluxing solution of $\mathrm{Cu}(\mathrm{acac})_{2}(46 \mathrm{mg}, 10 \mathrm{~mol} \%)$ in $\mathrm{THF}(20 \mathrm{~mL})$. The solution was stirred at reflux for $30 \mathrm{~min}$ and then cooled to room temperature. The solvent was removed in vacuo and the residue was purified by flash column chromatography on silica gel (hexane-diethyl ether, 10:1) to afford the ketone $\mathbf{6 b}$ as a white solid (607 mg, 88\%), which was recrystallized from hexane: m.p. $56-58{ }^{\circ} \mathrm{C} ;[\alpha]^{27}{ }_{\mathrm{D}}+85(\mathrm{c}=0.46$, $\left.\mathrm{CHCl}_{3}\right)$; IR $\left(\mathrm{CHCl}_{3}\right)$ 2932, 2860, 1754, 1112, $998 \mathrm{~cm}^{-1} ;{ }^{1} \mathrm{H}$ NMR (400 MHz, $\left.\mathrm{CDCl}_{3}\right) \delta 7.68-7.63(\mathrm{~m}$, 4H), 7.47-7.36 (m, 6H), 5.95-5.85 (m, 1H), 5.18-5.13 (m, 1H), 5.13-5.10 (m, 1H), 4.53-4.47 (m, 1H), $4.16(\mathrm{~d}, \mathrm{~J}=3.5 \mathrm{~Hz}, 1 \mathrm{H}), 3.96(\mathrm{dd}, \mathrm{J}=11.0,3.2 \mathrm{~Hz}, 1 \mathrm{H}), 3.64(\mathrm{dd}, \mathrm{J}=11.0,2.8 \mathrm{~Hz}, 1 \mathrm{H}), 2.67-2.59(\mathrm{~m}$, 1H), $2.55(\mathrm{dd}, \mathrm{J}=18.0,6.7 \mathrm{~Hz}, 1 \mathrm{H}), 2.51(\mathrm{dd}, \mathrm{J}=18.0,3.2 \mathrm{~Hz}, 1 \mathrm{H}), 1.03(\mathrm{~d}, \mathrm{~J}=6.9 \mathrm{~Hz}, 3 \mathrm{H}), 1.03(\mathrm{~s}$, $9 \mathrm{H}) ;{ }^{13} \mathrm{C} \mathrm{NMR}\left(100 \mathrm{MHz}, \mathrm{CDCl}_{3}\right) \delta 215.6,139.9,135.6,132.9,129.9,127.9,115.1,83.2,75.9,67.6$, 40.0, 39.2, 26.8, 19.2, 13.6; LRMS (CI, $\left.\mathrm{CH}_{4}\right) \mathrm{m} / \mathrm{z} 409\left(\mathrm{M}^{+}+1,10\right), 323$ (45), 239 (43), 227 (100), 199 (31), 125 (32); HRMS (CI, $\mathrm{CH}_{4}$ ) for $\mathrm{C}_{25} \mathrm{H}_{33} \mathrm{SiO}_{3}\left[(\mathrm{M}+\mathrm{H})^{+}\right]$calcd 409.2198, found 409.2184.

\section{Carboxylic Acid 7}

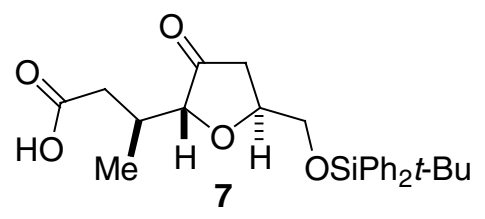

Cyclohexene $(1.0 \mathrm{~mL}, 9.8 \mathrm{mmol})$ was added at $0{ }^{\circ} \mathrm{C}$ to a solution of $\mathrm{BH}_{3}$.THF complex in THF $(0.5 \mathrm{M}, 9.8 \mathrm{~mL}, 4.9 \mathrm{mmol})$. The solution was stirred at $0{ }^{\circ} \mathrm{C}$ for $1 \mathrm{~h}$, resulting in a white slurry. A solution of the alkene $\mathbf{6 b}(400 \mathrm{mg}, 0.979 \mathrm{mmol})$ in THF $(10 \mathrm{~mL})$ was added to the slurry, dropwise. The ice bath was removed and stirring continued for $3 \mathrm{~h}$. The excess borane was quenched by the addition of methanol, a pH 7 buffered solution of $\mathrm{H}_{2} \mathrm{O}_{2}$ was added, and the solution was stirred overnight. Extraction (ethyl acetate), drying $\left(\mathrm{MgSO}_{4}\right)$ and removal of the solvent afforded a colourless liquid. Flash column chromatography on silica gel (hexane-diethyl ether, 1:4) afforded a mixture of epimeric diols (360 mg, $86 \%)$. 
Pyridinium dichromate $(3.8 \mathrm{~g}, 10 \mathrm{mmol})$ was added in one portion to a solution of the diols $(740 \mathrm{mg}$, $1.73 \mathrm{mmol})$ in dry DMF (35 mL) and the solution was stirred at room temperature for $48 \mathrm{~h}$. Dilute aqueous $\mathrm{HCl}(\mathrm{pH} \mathrm{3,70} \mathrm{mL)} \mathrm{was} \mathrm{added} \mathrm{and} \mathrm{the} \mathrm{aqueous} \mathrm{layer} \mathrm{was} \mathrm{extracted} \mathrm{(ethyl} \mathrm{acetate).} \mathrm{The} \mathrm{combined}$ organic extracts were dried $\left(\mathrm{MgSO}_{4}\right)$ and evaporated. The residue was purified by flash column chromatography on silica gel (petrol 40-60-ethyl acetate, 3:1) to afford the carboxylic acid 7 as a colourless oil (565 mg, $1.28 \mathrm{mmol}, 74 \%):[\alpha]^{21}{ }_{\mathrm{D}}+67$ (c = 0.51, $\left.\mathrm{CHCl}_{3}\right)$; IR $\left(\mathrm{CHCl}_{3}\right)$ 3183, 2930, 2859, 1754, 1709, $1112 \mathrm{~cm}^{-1} ;{ }^{1} \mathrm{H}$ NMR (400 MHz, $\mathrm{CDCl}_{3}$ ) $\delta$ 7.67-7.62 (m, 4H), 7.48-7.37 (m, 6H), 4.50-4.45 $(\mathrm{m}, 1 \mathrm{H}), 4.15(\mathrm{~d}, \mathrm{~J}=3.8 \mathrm{~Hz}, 1 \mathrm{H}), 3.96(\mathrm{dd}, \mathrm{J}=11.0,3.0 \mathrm{~Hz}, 1 \mathrm{H}), 3.63(\mathrm{dd}, \mathrm{J}=11.0,2.7 \mathrm{~Hz}, 1 \mathrm{H}), 2.62-$ $2.55(\mathrm{~m}, 3 \mathrm{H}), 2.46-2.39(\mathrm{~m}, 1 \mathrm{H}), 2.31(\mathrm{dd}, \mathrm{J}=15.5,7.6 \mathrm{~Hz}, 1 \mathrm{H}), 1.02(\mathrm{~s}, 9 \mathrm{H}), 0.97(\mathrm{~d}, \mathrm{~J}=6.8 \mathrm{~Hz}, 3 \mathrm{H})$, ${ }^{13} \mathrm{C}$ NMR $\left(100 \mathrm{MHz}, \mathrm{CDCl}_{3}\right) \delta 215.5,117.6,135.7,135.6,132.9,130.0,129.9,127.9,82.3,75.8,67.6$, 39.3, 37.5, 32.7, 26.8, 19.2, 14.5; LRMS (CI, $\left.\mathrm{CH}_{4}\right)$ m/z $440\left(\mathrm{M}^{+}, 4\right), 423$ (19), 305 (42), 277 (100), 233 (82), 161 (62); HRMS (CI, $\mathrm{CH}_{4}$ ) for $\mathrm{C}_{25} \mathrm{H}_{32} \mathrm{SiO}_{5}\left[\mathrm{M}^{+}\right]$calcd 440.2019, found 409.2017.

\section{Ester 8}

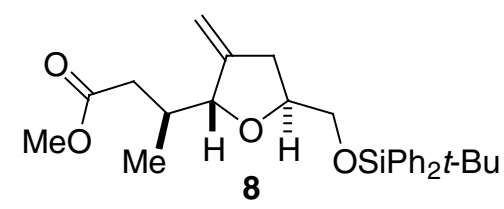

A solution of the acid $7(127 \mathrm{mg}, 0.29 \mathrm{mmol})$ in ether $(10 \mathrm{~mL})$ was added at room temperature to a solution of diazomethane (excess) in ether. The solution was stirred at room temperature for $1 \mathrm{~h}$ and nitrogen was then bubbled through the solution for $30 \mathrm{~min}$. The solvent was removed and the residue purified by flash column chromatography on silica gel (hexane-diethyl ether, 5:1) to give the methyl ester as a white solid (129 mg, $0.29 \mathrm{mmol}, 99 \%)$.

A solution of titanium(IV) chloride (1M in dichloromethane, $0.38 \mathrm{~mL}, 0.38 \mathrm{mmol})$ was added slowly to a solution of the Nysted reagent $(20 \mathrm{~mol} \%$ in THF, $0.96 \mathrm{~mL})$ in $\mathrm{THF}(1 \mathrm{~mL})$ at $0{ }^{\circ} \mathrm{C}$. The resulting slurry was stirred at $0{ }^{\circ} \mathrm{C}$ for $5 \mathrm{~min}$ and a solution of the above ketone $(83.0 \mathrm{mg}, 0.188 \mathrm{mmol})$ in THF (2 $\mathrm{mL}$ ) was added dropwise. The reaction was stirred at $0{ }^{\circ} \mathrm{C}$ for $10 \mathrm{~min}$ and left to warm slowly up to room temperature. When no starting material was seen on TLC diagnosis (ca. $5 \mathrm{~h}$ ), the reaction was quenched by addition of a dilute solution of $\mathrm{HCl}(\mathrm{pH} 3,5 \mathrm{~mL})$. The aqueous layer was extracted (diethyl ether) and the combined organic extracts dried $\left(\mathrm{MgSO}_{4}\right)$ and evaporated. The residue was purified by flash column chromatography on silica gel (hexane-diethyl ether, 20:1) to afford the alkene $\mathbf{8}$ as a colourless oil (58 $\mathrm{mg}, 0.13 \mathrm{mmol}, 67 \%, 81 \%$ based on recovered starting material): $[\alpha]_{\mathrm{D}}^{19}+52\left(\mathrm{c}=0.55, \mathrm{CHCl}_{3}\right)$; IR $\left(\mathrm{CHCl}_{3}\right)$ 2931, 2858, 1731, $1112 \mathrm{~cm}^{-1} ;{ }^{1} \mathrm{H}$ NMR (400 MHz, $\left.\mathrm{CDCl}_{3}\right) \delta$ 7.70-7.65 (m, 4H), 7.45-7.35 (m, $6 \mathrm{H}), 5.06(\mathrm{dd}, \mathrm{J}=4.3,2.2 \mathrm{~Hz}, 1 \mathrm{H}), 4.90(\mathrm{dd}, \mathrm{J}=4.3,2.1 \mathrm{~Hz}, 1 \mathrm{H}) ; 4.37-4.33(\mathrm{~m}, 1 \mathrm{H}), 4.25-4.18(\mathrm{~m}, 1 \mathrm{H})$, $3.64(\mathrm{dd}, \mathrm{J}=10.4,4.6 \mathrm{~Hz}, 1 \mathrm{H}), 3.59(\mathrm{dd}, \mathrm{J}=10.4,5.8 \mathrm{~Hz}, 1 \mathrm{H}), 2.71-2.63(\mathrm{~m}, 1 \mathrm{H}), 2.62-2.55(\mathrm{~m}, 1 \mathrm{H})$, 
$2.40(\mathrm{dd}, \mathrm{J}=11.8,8.9 \mathrm{~Hz}, 1 \mathrm{H}), 2.23-2.12(\mathrm{~m}, 2 \mathrm{H}), 1.45(\mathrm{~s}, 9 \mathrm{H}), 1.05$ (s, 9H), 0.89 (d, J = 6.4 Hz, 3H); ${ }^{13} \mathrm{C} \mathrm{NMR}\left(100 \mathrm{MHz}, \mathrm{CDCl}_{3}\right) \delta 173.8,149.6,135.7,133.7$ (C), 129.7, 127.7, 105.8, 83.5, 78.6, 66.3, 51.5, 38.4, 35.7, 35.6, 29.8, 26.9, 19.3, 13.7; LRMS (FAB) m/z $475\left(\mathrm{M}^{+}+23,9\right), 395$ (16), 241 (50), 135 (53), 69 (74), 57 (100); HRMS (FAB) for $\mathrm{C}_{26} \mathrm{H}_{34} \mathrm{SiO}_{5} \mathrm{Na}\left[(\mathrm{M}+\mathrm{Na})^{+}\right]$calcd 475.2281, found 475.2300.

\section{Ester 9}

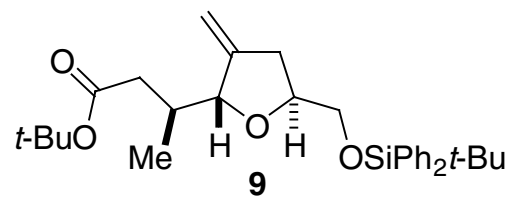

Oxalyl chloride $(0.06 \mathrm{~mL}, 0.7 \mathrm{mmol})$ was added to a solution of the acid 7 (100 $\mathrm{mg}, 0.227 \mathrm{mmol})$ in dry dichloromethane $(5 \mathrm{~mL})$, followed by one drop of dry DMF. The solution was stirred at room temperature overnight and a solution of $t$-butyl alcohol (excess) in dichloromethane was added. Stirring was continued for $8 \mathrm{~h}$ and solvent removed in vacuo. The residue was purified by flash column chromatography on silica gel (hexane-diethyl ether, 10:1) to afford the corresponding $t$-butyl ester as a white solid (101 mg, 88\%).

A solution of titanium(IV) chloride (1M in dichloromethane, $0.25 \mathrm{~mL}, 0.25 \mathrm{mmol}$ ) was added slowly at $0{ }^{\circ} \mathrm{C}$ to a solution of the Nysted reagent $(20 \mathrm{~mol} \%$ in THF, $0.7 \mathrm{~mL}$.) and THF $(1 \mathrm{~mL})$. The resulting slurry was stirred at $0{ }^{\circ} \mathrm{C}$ for $5 \mathrm{~min}$ and a solution of the above ketone $(61 \mathrm{mg}, 0.12 \mathrm{mmol})$ in THF $(2 \mathrm{~mL})$ was added dropwise. The reaction was stirred at $0{ }^{\circ} \mathrm{C}$ for $10 \mathrm{~min}$ and left to warm slowly up to room temperature and stirred for $5 \mathrm{~h}$. The reaction was quenched by addition of a dilute solution of $\mathrm{HCl}(5 \mathrm{~mL})$. The aqueous layer was extracted (diethyl ether, $3 \times 10 \mathrm{~mL}$ ) and the combined organic extracts dried $\left(\mathrm{MgSO}_{4}\right)$ and evaporated. The residue was purified by flash column chromatography on silica gel (hexane-diethyl ether, 20:1) to afford the alkene 9 as a colourless oil (52 mg, $0.105 \mathrm{mmol}, 86 \%):[\alpha]^{20}{ }_{\mathrm{D}}$ +40 (c = 0.86, $\mathrm{CHCl}_{3}$ ); IR (liquid film) 2960, 2929, 2857, 1727, $1112 \mathrm{~cm}^{-1} ;{ }^{1} \mathrm{H} \mathrm{NMR} \mathrm{(400} \mathrm{MHz,} \mathrm{CDCl}_{3}$ ) $\delta$ 7.70-7.65 (m, 4H), 7.45-7.35 (m, 6H), $5.06(\mathrm{dd}, \mathrm{J}=4.3,2.2 \mathrm{~Hz}, 1 \mathrm{H}), 4.90(\mathrm{dd}, \mathrm{J}=4.3,2.1 \mathrm{~Hz}, 1 \mathrm{H})$; 4.37-4.33 (m, 1H), 4.25-4.18 (m, 1H), 3.64 (dd, J = 10.4, 4.6 Hz, 1H), 3.59 (dd, J = 10.4, 5.8 Hz, 1H), 2.71-2.63 (m, 1H), 2.62-2.55 (m, 1H), 2.40 (dd, J = 11.8, 8.9 Hz, 1H), 2.23-2.12 (m, 2H), 1.45 (s, 9H), 1.05 (s, 9H), 0.89 (d, J = 6.4 Hz, 3H); ${ }^{13} \mathrm{C}$ NMR (100 MHz, $\left.\mathrm{CDCl}_{3}\right) \delta$ 172.7, 149.7, 135.7, 133.7, 129.7, 127.7, 105.8, 83.8, 80.2, 78.6, 66.3, 39.8, 35.8, 35.7, 28.2, 26.9, 19.3, 13.6; LRMS (CI, NH 3$)$ m/z 495 $\left(\mathrm{M}^{+}+1,6\right), 456$ (6), 421 (20), 381 (35), 303 (100), 241 (79), 199 (82), 181 (84); HRMS (CI, $\left.\mathrm{NH}_{3}\right)$ for $\mathrm{C}_{30} \mathrm{H}_{42} \mathrm{SiO}_{4}\left[(\mathrm{M}+\mathrm{H})^{+}\right]$calcd 495.2931, found 495.2909. 


\section{Alcohol 10}

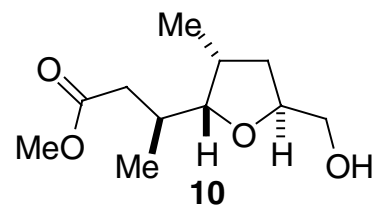

A solution of TBAF (1M in THF, $0.07 \mathrm{~mL}, 0.07 \mathrm{mmol})$ was added at $0{ }^{\circ} \mathrm{C}$ to a solution of the alkene 8 (44.0 mg, $0.0972 \mathrm{mmol}$ ) in THF (2 mL). The solution was left to warm to at room temperature over $3 \mathrm{~h}$ and a saturated solution of $\mathrm{NH}_{4} \mathrm{Cl}(5 \mathrm{~mL})$ was added. The aqueous layer was extracted (diethyl ether) and the combined organic extracts were dried $\left(\mathrm{MgSO}_{4}\right)$ and evaporated. The crude residue was purified by flash column chromatography on silica gel (hexane-diethyl ether, 1:1) to afford the alkene as a colourless oil (21.0 mg, 99\%).

A solution of the above alkene $(20.0 \mathrm{mg}, 0.0933 \mathrm{mmol})$ and Wilkinson's catalyst $(8.5 \mathrm{mg})$ in dry toluene $(5 \mathrm{~mL})$ was degassed several times under vacuum and each time the atmosphere was replaced by an atmosphere of hydrogen. The solution was then stirred at room temperature under an atmosphere of hydrogen until no starting material was observed by TLC analysis. The solution was then evaporated and the residue purified by flash column chromatography on silica gel (dichloromethane-diethyl ether, 2:1) to afford the alcohol 10 as a colourless liquid $(19.0 \mathrm{mg}, 95 \%)$ : $[\alpha]^{27}+2.1\left(\mathrm{c}=0.15, \mathrm{CHCl}_{3}\right) ; \mathrm{IR}\left(\mathrm{CHCl}_{3}\right)$ 2969, 1731, 1374, 1046; ${ }^{1} \mathrm{H}$ NMR (500 MHz, $\left.\mathrm{CDCl}_{3}\right) \delta 4.25-4.18$ (m, 1H), 3.69 (s, 3H), 3.64-3.59 (m, $1 \mathrm{H}), 3.54(\mathrm{dd}, J=8.9,4.4 \mathrm{~Hz}, 1 \mathrm{H}), 3.50-3.44(\mathrm{~m}, 1 \mathrm{H}), 2.36(\mathrm{dd}, J=14.1,3.1 \mathrm{~Hz}, 1 \mathrm{H}), 2.33-2.28(\mathrm{~m}$, $1 \mathrm{H}), 2.15-2.03(\mathrm{~m}, 2 \mathrm{H}), 1.92-1.87(\mathrm{~m}, 1 \mathrm{H}), 1.85(\mathrm{ddd}, J=12.5,8.6,6.8 \mathrm{~Hz}, 1 \mathrm{H}), 1.70(\mathrm{ddd}, J=12.5$, 6.9, $2.0 \mathrm{~Hz}, 1 \mathrm{H}), 1.08(\mathrm{~d}, J=6.3 \mathrm{~Hz}, 1 \mathrm{H}), 0.98(\mathrm{~d}, J=7.0 \mathrm{~Hz}, 3 \mathrm{H}) ;{ }^{13} \mathrm{C} \mathrm{NMR}\left(125 \mathrm{MHz}, \mathrm{CDCl}_{3}\right) \delta 173.0$, 85.2, 77.4, 65.7, 51.7, 38.4, 36.0, 35.3, 31.7, 17.6, 14.0; LRMS (CI, $\left.\mathrm{NH}_{3}\right), \mathrm{m} / \mathrm{z} 217\left(\mathrm{M}^{+}+1,95\right), 185$ (100), 167 (58), 142 (61), 125 (56), 115 (63); HRMS (CI, $\mathrm{NH}_{3}$ ) for $\mathrm{C}_{11} \mathrm{H}_{21} \mathrm{O}_{4}\left[(\mathrm{M}+\mathrm{H})^{+}\right]$calcd 217.1440, found 217.1447.

\section{Alcohol 11}

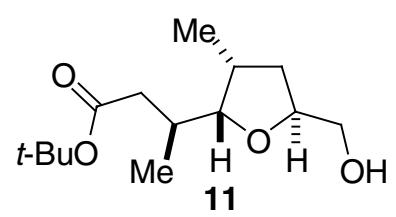

A solution of TBAF (1M in THF, $1.20 \mathrm{~mL}, 1.20 \mathrm{mmol}$ ) was added at $0^{\circ} \mathrm{C}$ to a solution of the alkene $9(187 \mathrm{mg}, 0.378 \mathrm{mmol})$ in THF (2 mL). The solution was left to warm up to at room temperature over 3 $\mathrm{h}$ and a saturated solution of $\mathrm{NH}_{4} \mathrm{Cl}(5 \mathrm{~mL})$ was added. The aqueous layer was extracted (diethyl ether). The combined organic extracts were dried $\left(\mathrm{MgSO}_{4}\right)$ and evaporated, and the crude residue was purified 
by flash column chromatography on silica gel (hexane-diethyl ether, 1:1) to afford the alkene as a colourless oil (21.0 mg, 99\%).

A solution of the above alkene $(10.0 \mathrm{mg}, 0.0390 \mathrm{mmol})$ in dry toluene $(1 \mathrm{~mL})$ was degassed several times under vacuum and the atmosphere replaced by hydrogen each time. To this solution was added Wilkinson's catalyst $(2.5 \mathrm{mg})$ in one portion and the suspension was stirred at room temperature for $24 \mathrm{~h}$. The solvent was then removed in vасио and the residue purified by flash column chromatography on silica gel (dichloromethane-diethyl ether, 3:1) to afford the alcohol $\mathbf{1 1}$ as a colourless liquid (9.2 $\mathrm{mg}$, 92\%): $[\alpha]^{20}{ }_{\mathrm{D}}+1.3\left(\mathrm{c}=0.50, \mathrm{CHCl}_{3}\right.$ ); IR (liquid film) 3433, 2965, 2930, 2877, 1728, $1153 \mathrm{~cm}^{-1} ;{ }^{1} \mathrm{H}$ NMR $\left(400 \mathrm{MHz}, \mathrm{CDCl}_{3}\right) \delta 4.25-4.18(\mathrm{~m}, 1 \mathrm{H}), 3.61(\mathrm{dd}, \mathrm{J}=11.5,3.3 \mathrm{~Hz}, 1 \mathrm{H}), 3.52(\mathrm{dd}, \mathrm{J}=9.3,4.3 \mathrm{~Hz}, 1 \mathrm{H})$, $3.46(\mathrm{dd}, \mathrm{J}=11.5,6.7 \mathrm{~Hz}, 1 \mathrm{H}), 2.32-2.26(\mathrm{~m}, 1 \mathrm{H}), 2.26(\mathrm{dd}, \mathrm{J}=14.2,3.4 \mathrm{~Hz}, 1 \mathrm{H}), 2.12-2.01(\mathrm{~m}, 1 \mathrm{H})$, $1.93(\mathrm{dd}, \mathrm{J}=14.1,9.9 \mathrm{~Hz}, 1 \mathrm{H}), 1.86(\mathrm{br}, 1 \mathrm{H}), 1.84(\mathrm{ddd}, \mathrm{J}=12.5,8.7,6.7 \mathrm{~Hz}, 1 \mathrm{H}), 1.69$ (ddd, J = 12.5, 7.0, $1.8 \mathrm{~Hz}, 1 \mathrm{H}), 1.46(\mathrm{~s}, 9 \mathrm{H}), 1.08(\mathrm{~d}, \mathrm{~J}=6.4 \mathrm{~Hz}, 3 \mathrm{H}), 0.97(\mathrm{~d}, \mathrm{~J}=7.0 \mathrm{~Hz}, 3 \mathrm{H}) ;{ }^{13} \mathrm{C} \mathrm{NMR}(100 \mathrm{MHz}$, $\left.\mathrm{CDCl}_{3}\right) \delta 171.9,85.3,80.4,77.4,65.7,39.9,36.0,35.2,31.9,28.2,17.5,14.0 ;$ LRMS $\left(\mathrm{CI}, \mathrm{NH}_{3}\right) \mathrm{m} / \mathrm{z} 259$ $\left(\mathrm{M}^{+}+1,20\right), 203$ (100), 185 (59), 171 (59), 142 (55), 115 (68); HRMS (CI, $\left.\mathrm{NH}_{3}\right)$ for $\mathrm{C}_{14} \mathrm{H}_{26} \mathrm{O}_{4}\left[(\mathrm{M}+\mathrm{H})^{+}\right]$ calcd 259.1909, found 259.1917. 

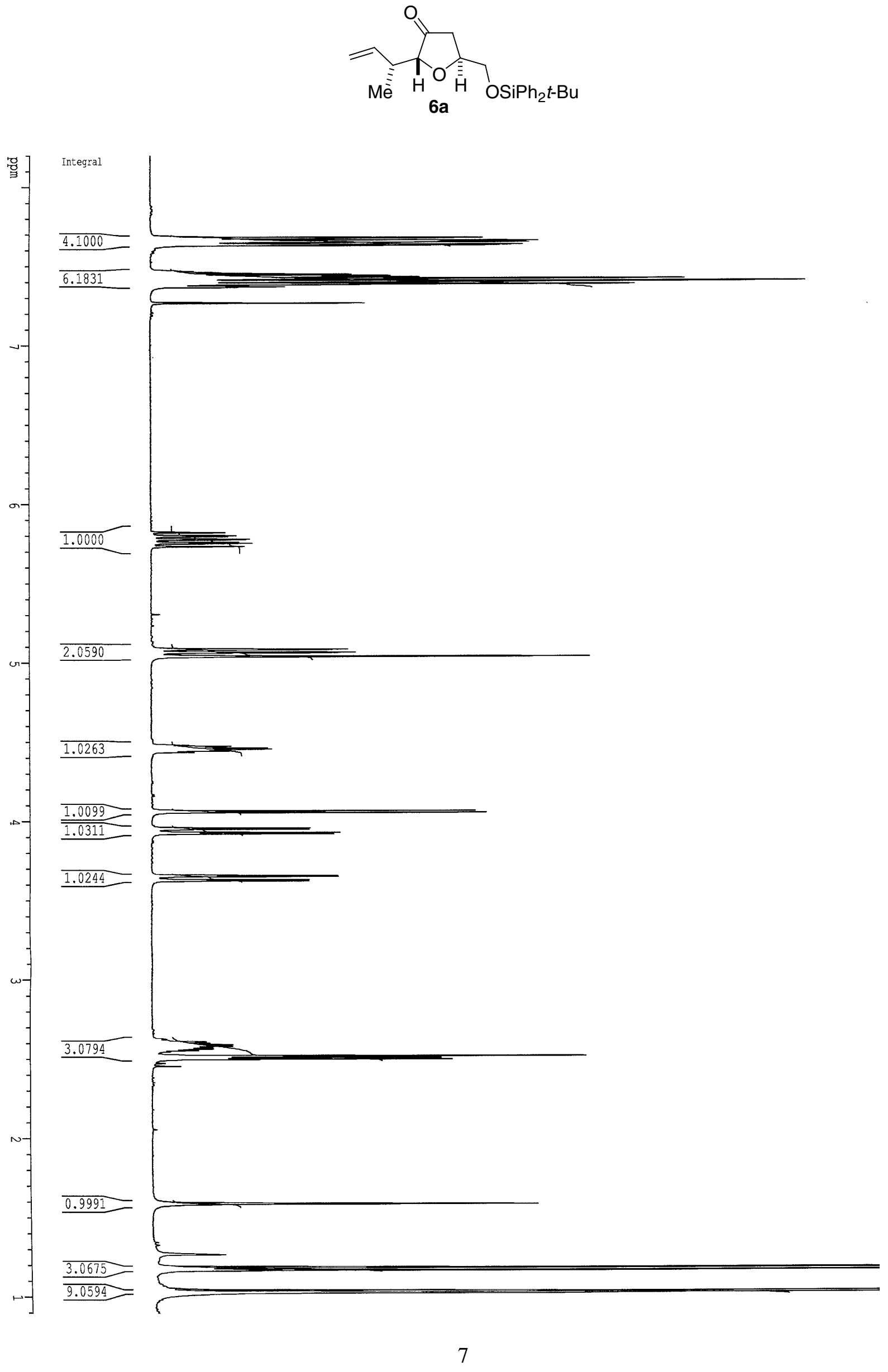


$$
\mid
$$




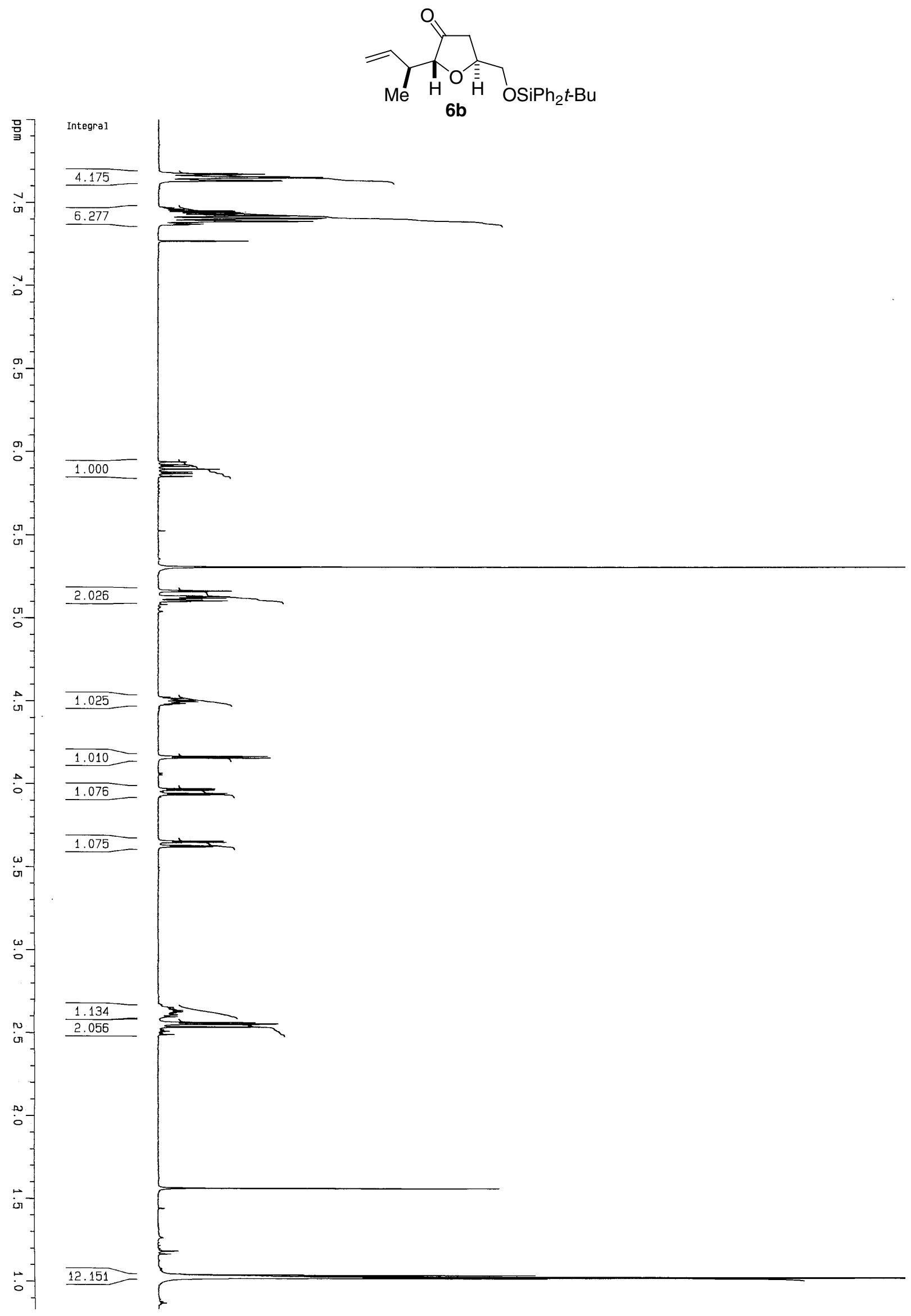




$$
\mid
$$



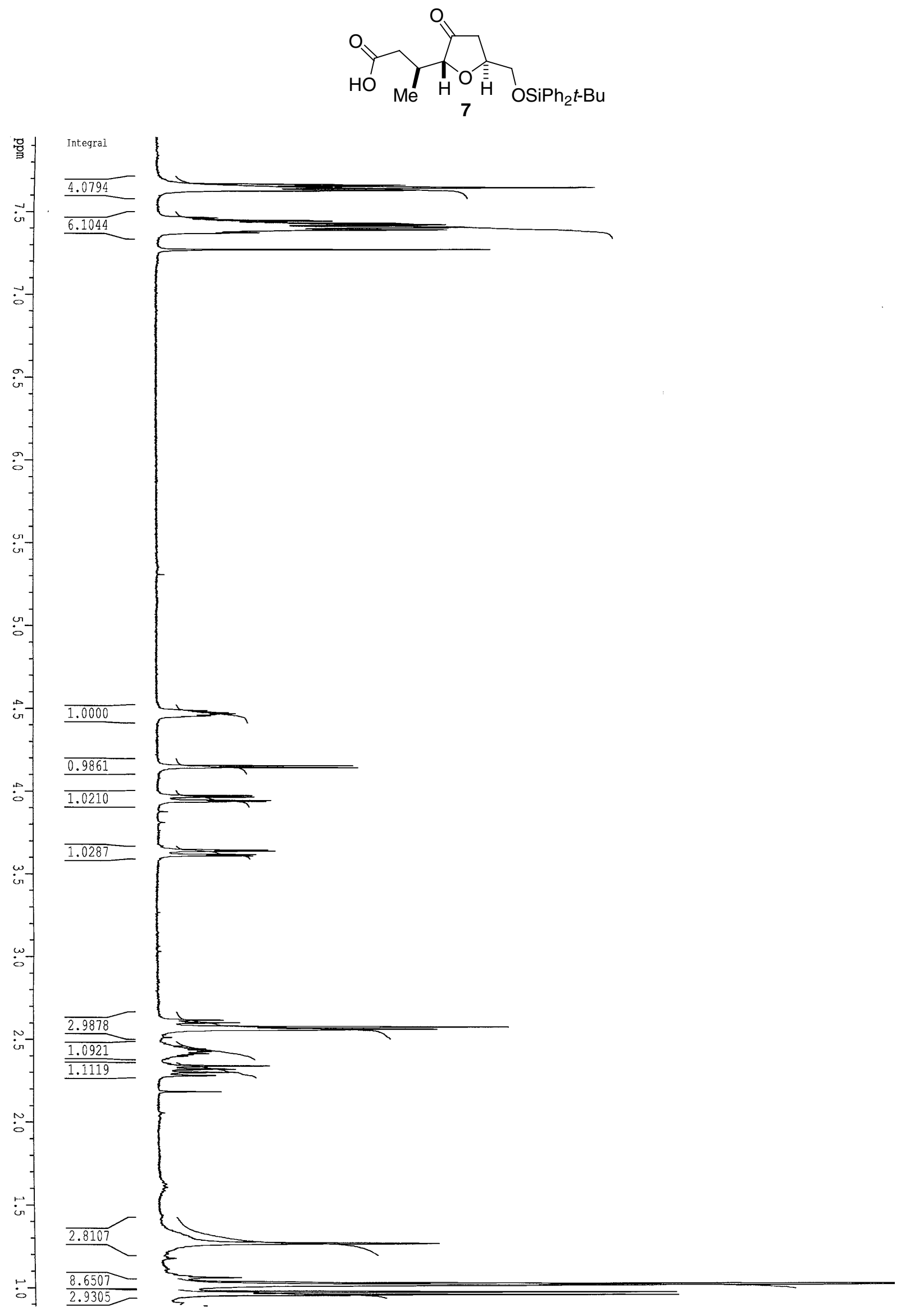


$$
E
$$



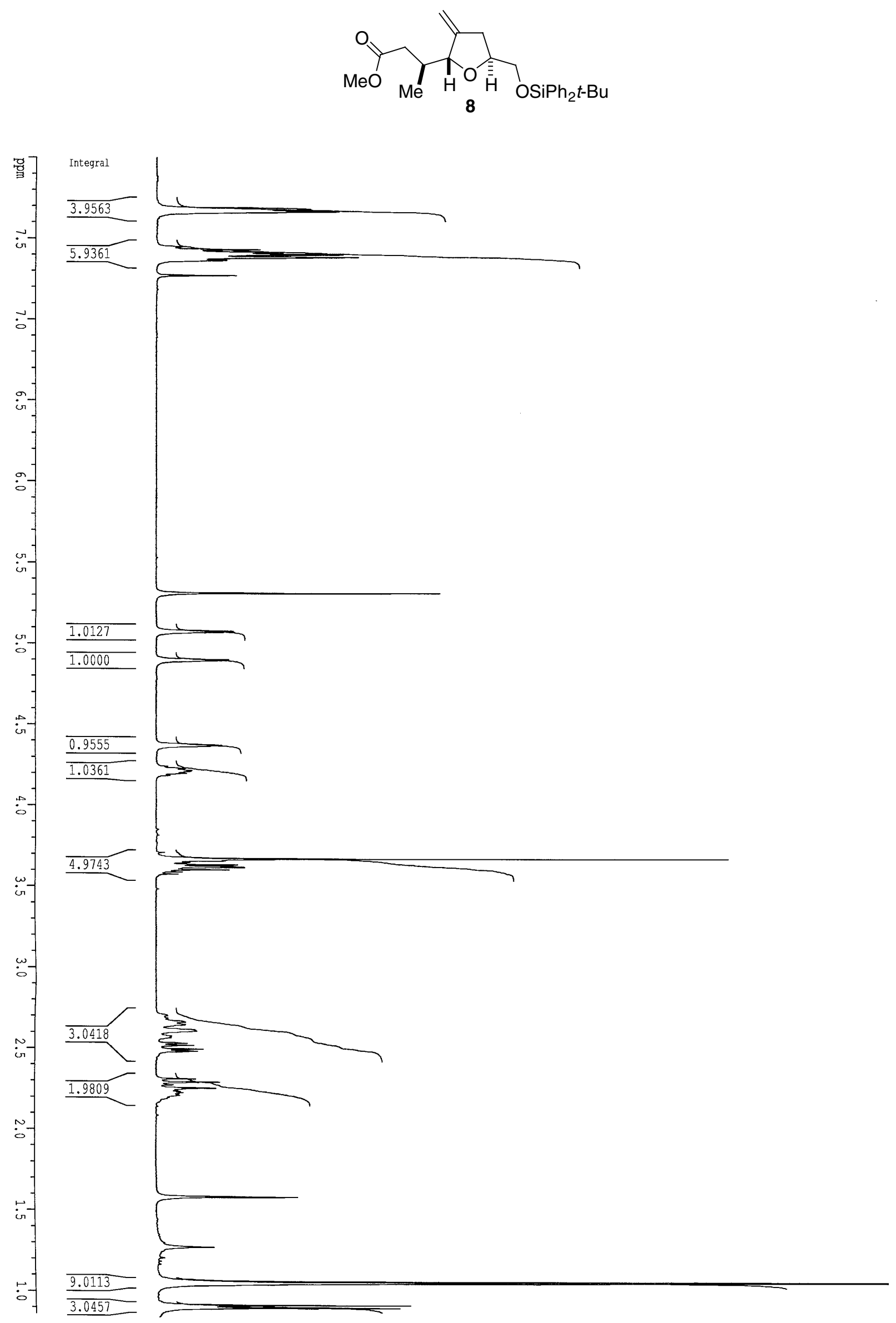

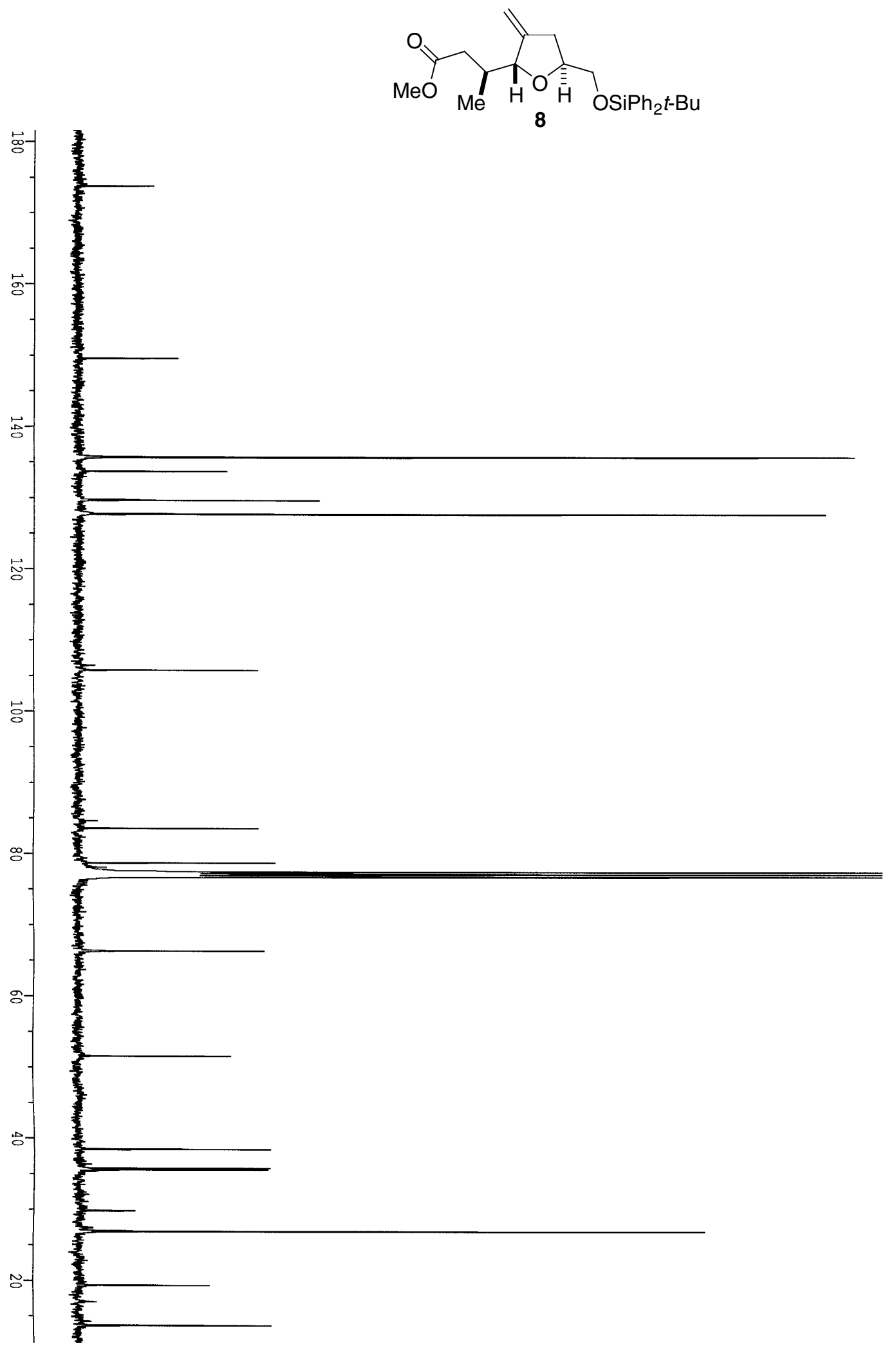

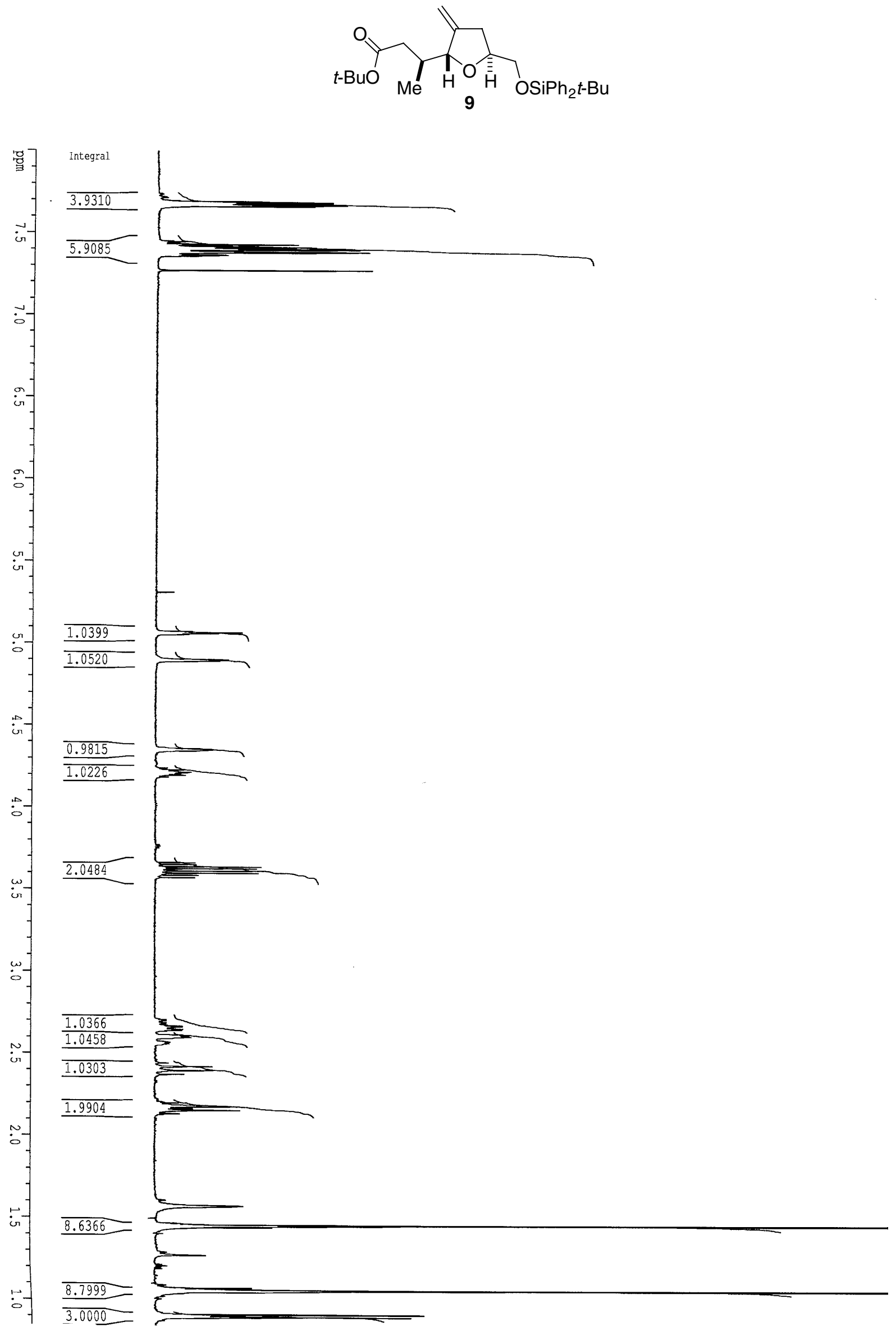

15 


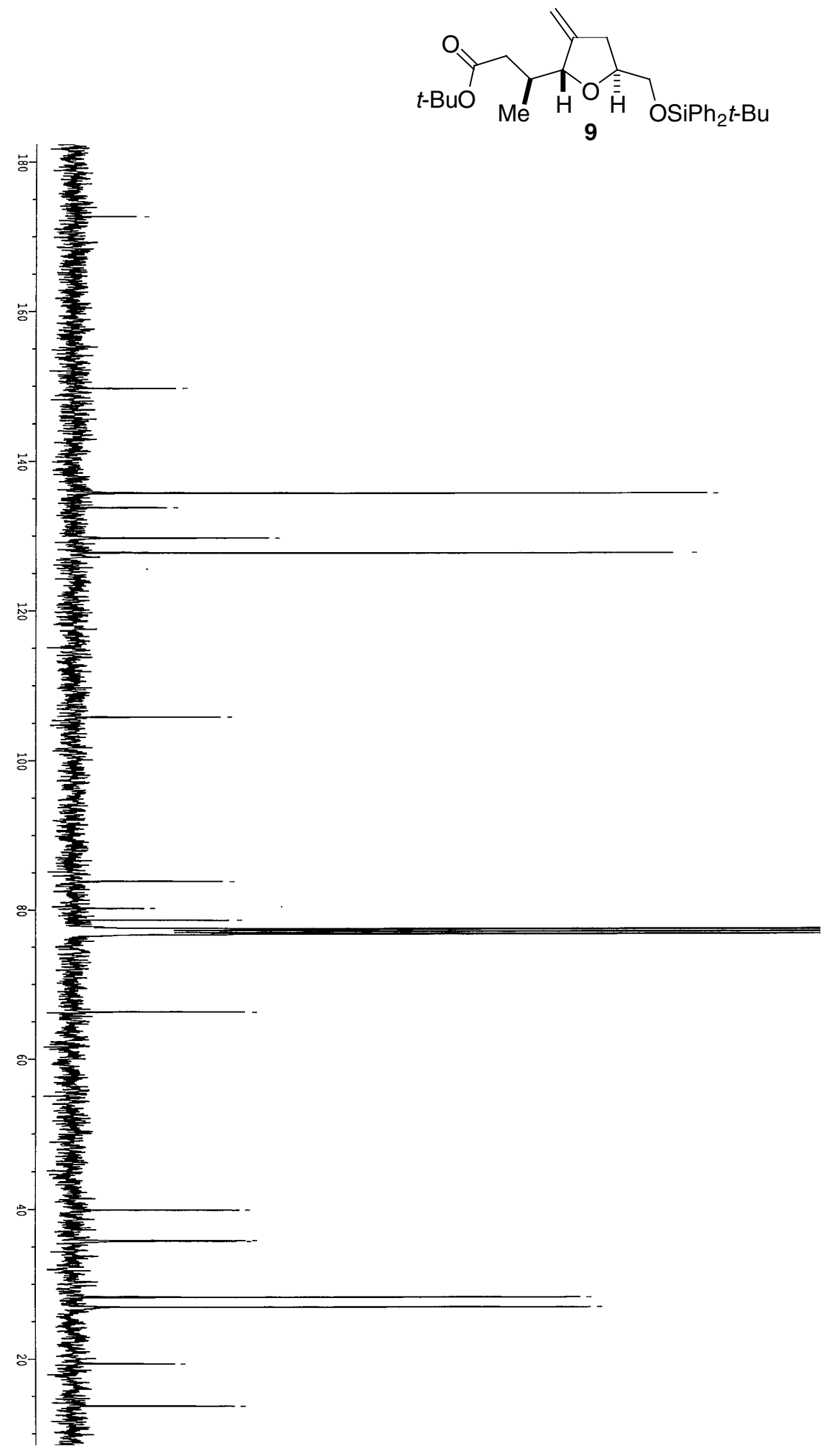




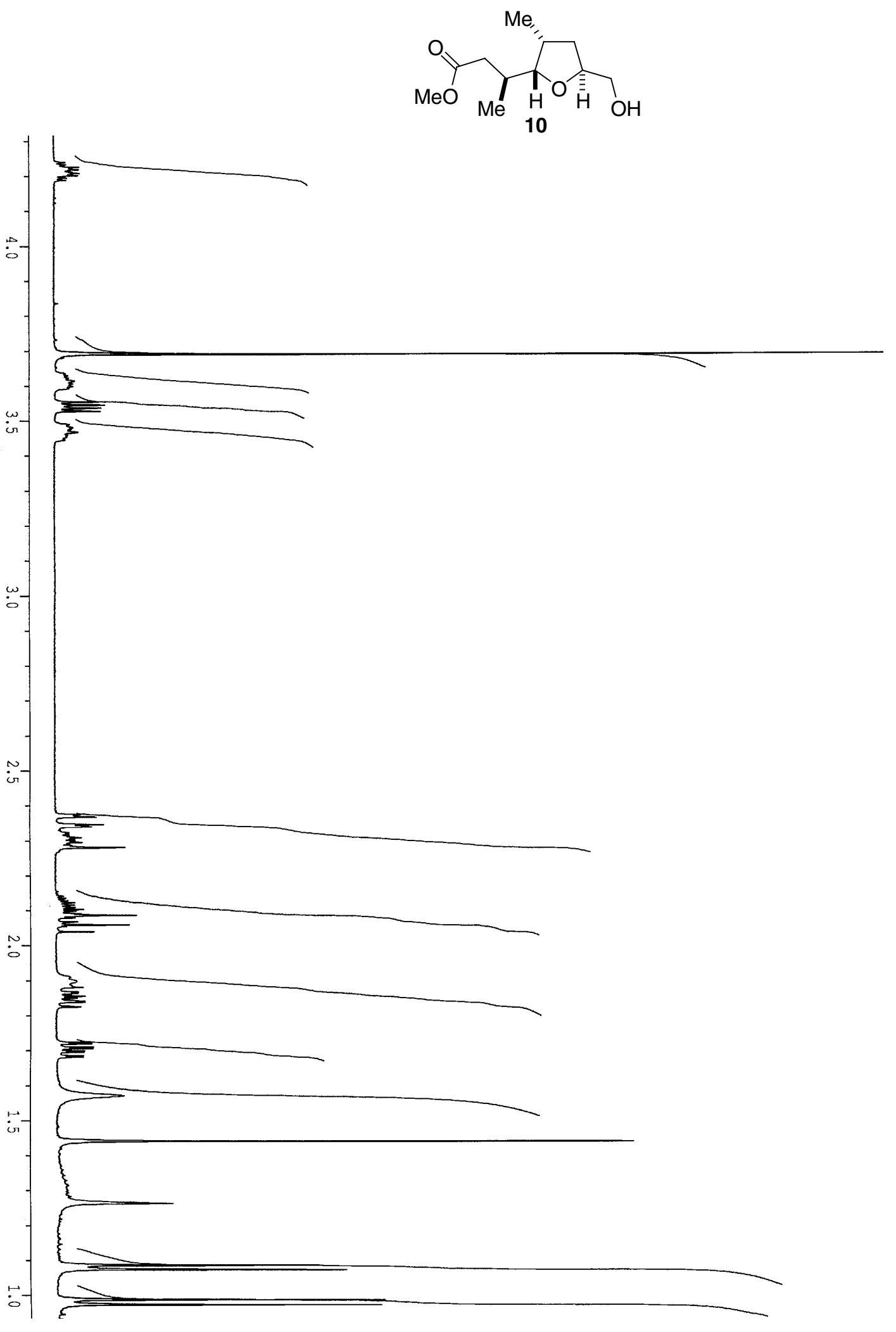


<smiles>COC(=O)C[C@@H](C)[C@H]1O[C@H](CO)C[C@H]1C</smiles>

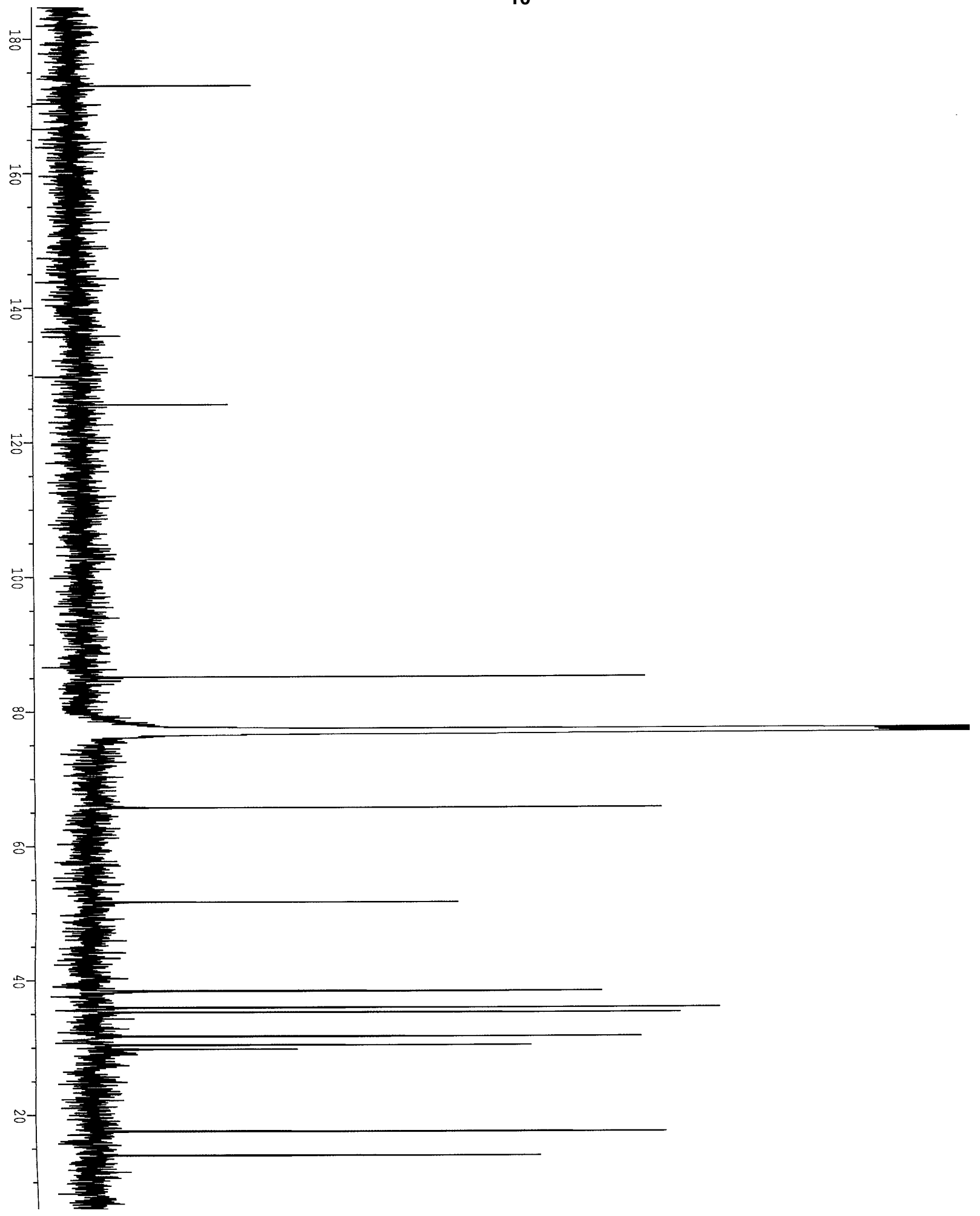

18 

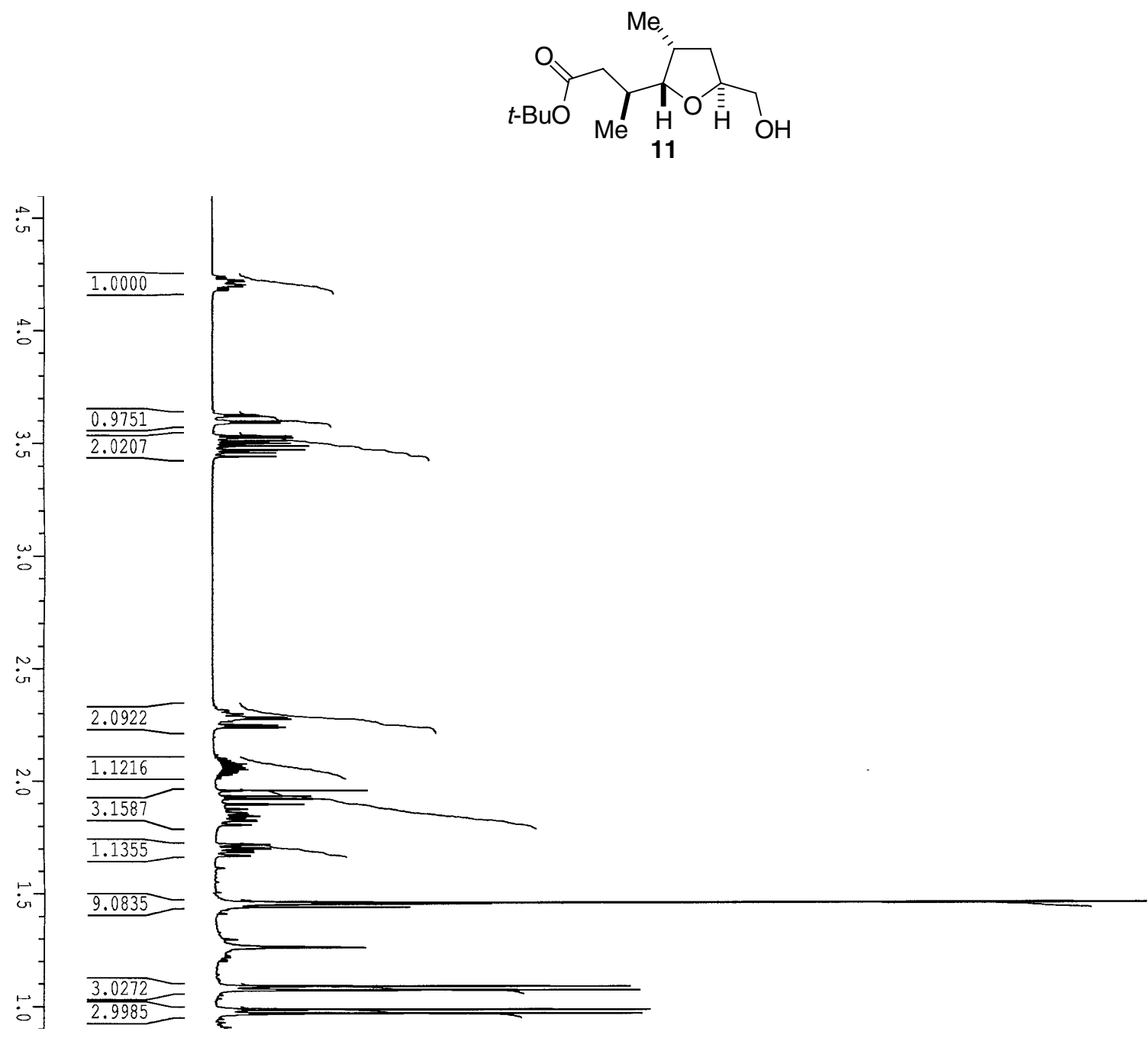


$$
E
$$

